\title{
Mensuration of Genitalia of Post-Partum Anestrous Murrah Buffaloes
}

\author{
Manoj Gupta ${ }^{1 *}$, V.K. Gandotra ${ }^{2}$, A.S. Nanda ${ }^{3}$ and M. Honparkhe ${ }^{2}$ \\ ${ }^{1} N D D B$, Bikaner, India \\ ${ }^{2}$ Department of Argo, GADVASU, Ludhiana, Punjab, India \\ ${ }^{3}$ GADVASU, Ludhiana, Punjab, India \\ *Corresponding author
}

\section{A B S T R A C T}

\begin{tabular}{|l|}
\hline K e y w or d s \\
Ovary, Cervix, \\
Ultrasound, \\
Buffalo, Genitalia \\
\hline Article Info \\
\hline $\begin{array}{l}\text { Accepted: } \\
\text { 12 September } 2018 \\
\text { Available Online: } \\
\text { 10 October } 2018\end{array}$ \\
\hline
\end{tabular}

Keywords

\section{Introduction}

According to $19^{\text {th }}$ livestock census 2012, buffalo plays a significant role in the economy of India by providing milk, meat and draught power. More than half of the world population of buffalo is housed in India.True-anoestrus is the most common cause of infertility in buffalo mainly caused by high ambient temperature, nutritional deficiency, poor management system and hormonal disturbances (Agrawal 2003). Normal size and texture of genitalia is essential for optimal reproductive performance of the animal. Changes therein due to various physiological or pathological conditions may affect the functional status. Pathological lesions such as congenital abnormalities, tumors, cysts and inflammatory conditions alter the shape and performance of genitalia (Sane et al., 1964), the exact knowledge of which is essential for undertaking corrective measures to optimize the reproductive performance. The ultrasound is a simple, reliable, non-invasive imaging technique without any side effects (Giuseppina, 2012). It's applications in veterinary practice has developed from a limited use for pregnancy diagnosis and detection of some pathological conditions like hydrometra or metritis, reproductive management of the herd (Giuseppina, 2012). Its use in ruminant reproduction like 
measuring genitalia in cyclic buffaloes (Agrawal and Tomar, 1998) and (Parkhe et al., 2004) and understanding of follicular dynamics (Baruselli et al., 1997; Manik et al., 1998), embryo production (Kitiyanant et al., 1995) and fetal development (Pawsche et al., 1994) in buffaloes have advanced our understanding in this area. However, such information was lacking in postpartum anoestrous buffaloes. In the present study, we tried to provide an overview of measurement of size of genital organs of postpartum anestrous buffaloes.

\section{Materials and Methods}

Study was performed on 16 postpartum healthy anoestrous Murrah buffaloes maintained at uniform condition and of standard feeding schedule of Dairy Farm, Punjab Agricultural University, Ludhiana in 2003. The animals were divided in Group-I(Control group-n=5) Group-II (Progesterone therapy group, $n=6$ )those were administered $750 \mathrm{mg}$ hydroxy progesterone hexanoate BP (Pregneforte $\AA$, Venus Remedies Limited, Panchkula, Haryana, i.m.) on days 1, 4 and 7 of the experiment \& Group-III (Progesterone + Pregnant Mare Serum Gonadotrophin therapy group, $n=6$ )- those were administered hydroxy progesterone hexanoate $\mathrm{BP}$ injection as in Group-II followed by 750 IU PMSG (Folligon ${ }^{\circledR}$, Intervet (India) Private Limited, Hyderabad, i.m.) on day 10 i.e. $72 \mathrm{~h}$ after $3^{\text {rd }}$ injection of progesterone.

\section{Ultrasound examination}

The measurement of genital organs made by a real time B-mode ultrasound scanner (Concept MCV, dynamic imaging, Scotland, U.K.) equipped with interchangeable 5/7.5 $\mathrm{MHz}$ linear-array rectal transducer without using of any drug in animals. The rectum was back racked before performing measurements of genitalia (Savio et al., 1988, Stagg et al., 1995 and Parkhe et al., 2004) in the following ways-

\section{Part of the genitalia - Observation site}

Cervix - Middle

Body of uterus - Anterior to internal os

Uterine horns - at the level of bifurcation

Ovaries - Anterior to posterior pole

The size of the lumen which appeared dark, anechoic area was measured using inbuilt electronic calipers after freezing the image.

\section{Statistical analysis}

The means of size of ovaries, uterine horns and cervix in various groups were compared each other using Student's t-test with the level of significance at $\mathrm{P}<0.05$ (Singh et al., 1991).

\section{Results and Discussion}

\section{Cervix}

The luminal diameter of cervix was significantly bigger $(\mathrm{P}<0.05)$ in Group-III $(1.67 \pm 0.051 \mathrm{~cm})$ as compared to that of Groups-I $(1.27 \pm 0.052 \mathrm{~cm})$ and II $(1.26 \pm 0.038$ $\mathrm{cm})$ buffaloes. Our findings are similar to that reported by Honparkhe et al., (2004). However, Agrawal and Tomar (1998) recorded slightly greater diameter of cervix (2$4 \mathrm{~cm}$ ).Similarly, in African zebu heifers and cows it is observed more than $3 \mathrm{~cm}$ diameter of cervical lumen (Bello et al., 2012).

The size of cervix varied with the stage of reproductive cycle and parity of the animal (Zemjanis, 1970 and Roberts, 1971). There is increased vascular development and oedema of genital organs as a result of high oestradiol concentration at oestrus (Garverick et al., 
1971 and Roberts, 1971). This might explain the observed significantly bigger size of cervix in Progesterone +PMSG treated buffaloes as four buffaloes became cyclic in this Group.

\section{Body of uterus}

The luminal diameter of uterine body was significantly greater $(\mathrm{P}<0.05)$ in Group-III $(1.47 \pm 0.037 \mathrm{~cm})$ as compared to that of Groups-I (1.28 $\pm 0.038 \mathrm{~cm})$ and II $(1.27 \pm 0.034$ $\mathrm{cm})$ buffaloes. The size of body of uterus in the present study is in agreement with the finding of Agrawal and Tomar (1998) and Honparkhe et al., (2004).

Resumption of cyclicity in the Progesterone + PMSG treated buffaloes may be accountable for the significantly bigger size of body of uterus in Group-III as compared to that in Groups I and II buffaloes.

\section{Uterine horn}

Overall mean luminal diameter of uterine horn varied between $1.13 \pm 0.045$ to $1.23 \pm 0.022 \mathrm{~cm}$ in all the buffaloes. There was no significant variation between the size of left and right uterine horn of the buffaloes in different groups. Also, the size of left and right uterine horn varied non-significantly among the Groups. Honparkhe et al., (2004) observed the mean size of left and right uterine horn was $1.64 \pm 0.037$ and $1.73 \pm 0.036 \mathrm{~cm}$, respectively in cycling buffaloes. He found significant $(\mathrm{P}<0.05)$ smaller size of right horn during late diestrus as compared to that in estrus $(1.40 \pm 0.21$ to $1.68 \pm 0.30$ vs $1.80 \pm 0.28$ to $2.00 \pm 0.47 \mathrm{~cm})$. The comparable size of left and right uterine horn has been recorded by Bhalla et al., (1964) and Sane et al., (1964). The variation in the size of uterine horn may occur due to parity (Roberts, 1971).

Table.1 Size of tubular genitalia and ovaries $(\mathrm{cm})($ Mean \pm SE) in anestrous buffaloes

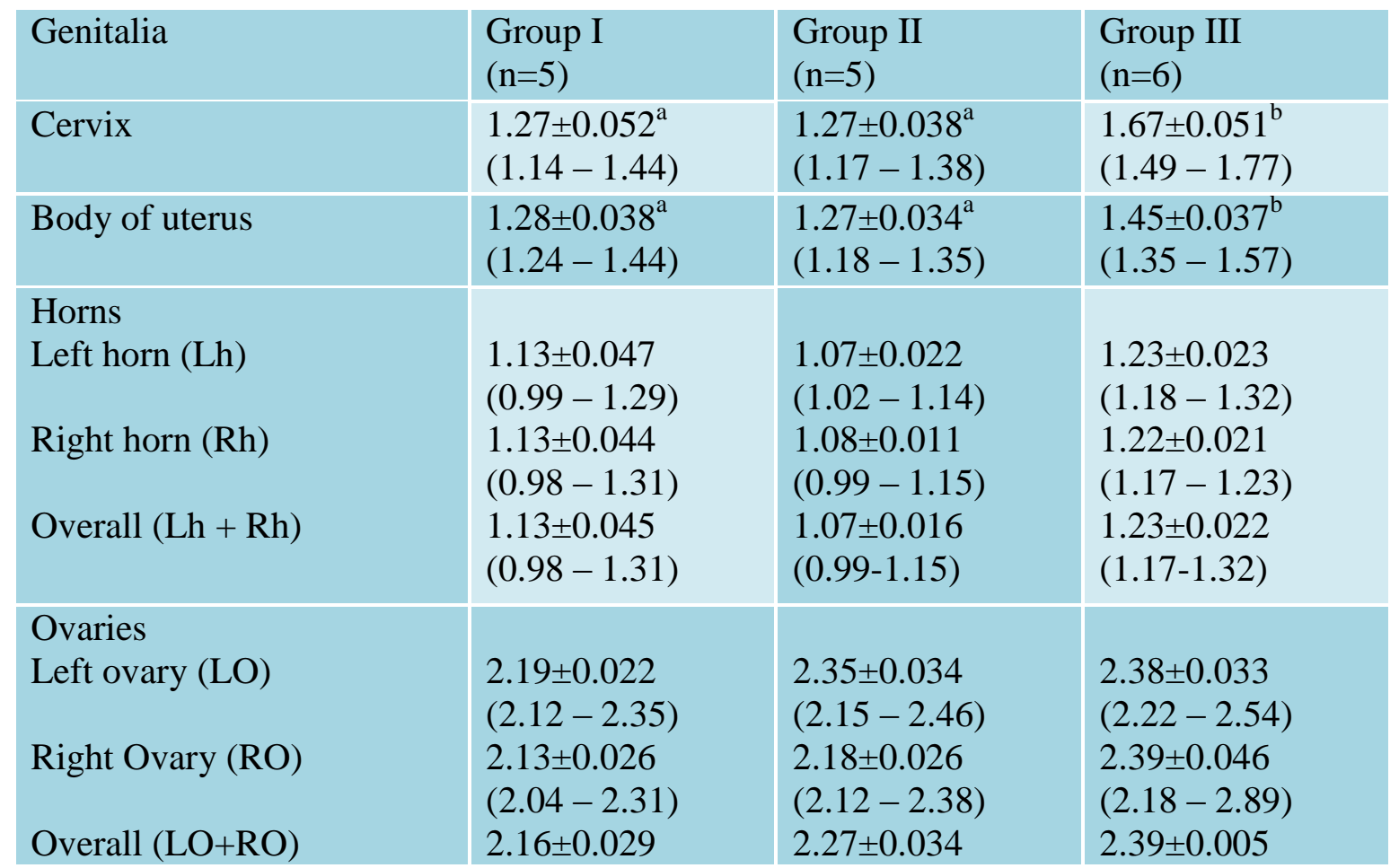

Value with different superscript within the same rows shows significant difference $(\mathrm{P}<0.05)$.Values in parenthesis indicate range. 


\section{Ovaries}

Overall mean size of ovaries was $2.16 \pm 0.029$, $2.27 \pm 0.034$ and $2.39 \pm 0.005 \mathrm{~cm}$ in Groups-I, II and III buffaloes, respectively. No significant differences $(\mathrm{P}>0.05)$ in the mean size of left and right ovaries were found in between and within the Groups of buffaloes (Table 1). Similar size of the ovaries have been recorded by Sane et al., (1964), Honparkhe et al., (2004), Khaton et al., (2015) and Parkale and Hukeri (1989).

In the present study, the luminal diameter of cervix and uterine body were significantly bigger in Group-III as compared to that of Group-I and II buffaloes. However, no significant different were found in overall mean luminal diameter of uterine horns and mean size of ovaries in different groups of buffaloes.

\section{Acknowledgement}

The authors are thankful to Punjab Agriculture University, Ludhiana for providing necessary support to conduct the study. Also, thanks to Dr Harish Verma, Director Extension GADVASU for his valuable guidance.

\section{References}

Agrawal K P (2003) Augmentation of reproduction in buffaloes. $4^{\text {th }}$ Asian Buffalo Congress: New Delhi, India. pp 121-27.

Agrawal S K and Tomar O S. 1998. Reproductive Techniques in Buffaloes. $p$ 6-24 Bytes and Bytes, Barielly.

Baruselli, P. S., R. G. Mucciolo, J. A. Visintin, W. G. Viana, R. P.Arruda, E. H. Madureira and J. R. Oliveira Molero Filho. 1997. Ovarian follicular dynamics during estrous cycle in buffalo (Bubalus bubalis).

Theriogenology, 47:1531-1547.

Bhalla R C, Sengar D P S and Jain G C. 1964. Biometry of genital tract of buffalo cows. Indian J Vet Sci., 41: 327-31.

Garverick H A, Erb R E and Niswinder G D. 1971. Reproductive streoids in the bovine III, Changes during the oestrous cycle. J Anim Sci., 32: 946-56.

Giuseppina Maria Terzano 2012. Ultrasonography and Reproduction in Buffalo. Journal of Buffalo Science-1: 163-173.

Honparkhe, M., Gandotra V. K. and Nanda A. S. 2004. Ultrasonographic Measurements in Comparison with the Rectal Palpation and Echotexture of Reproductive Organs of Buffaloes (Bubalus bubalis) during Different Stages of the Estrous Cycle. Asian-Aust. J. Anim. Sci. 2004. Vol 17, No. 7: 919923.

Khaton R., Sarder M.J.U. and Gofur M.R. 2015. Biometrical Studies of Reproductive Organs of Dairy Cows of Different Genotypes in Bangladesh. Asian Journal of Animal Sciences 9 (6): 388-395.

Kitiyanant, Y., C. Tocharus, M. Areekijseree and K. Pavasuthipaisit. 1995. Swamp buffalo oocytes from transvaginal ultrasound guided aspiration fertilized and cocultured in vitro with bovine oviductal epithelial cells. Theriogenology 43:250.

Manik, R. S., S. K Singla, P. Palta and M. L. Madan. 1998. Realtime ultrasound evaluation of changes in follicular populations during estrous cycle in buffalo. Indian J. Anim. Sci. 68:11571159.

Parkale D D., and Hukeri V B. 1989. Study of biometry of buffalo (Bos bubalis) ovaries. Indian J Anim Reprod10: 1719. 
Pawsche, C. H., K. B. C. Appa Rao and S. M. Totey. 1994. Ultrasonographic imaging to monitor early pregnancy andembryonic development in buffaloes (Bubalus bubalis). Theriogenology 41:697-709.

Roberts S J. 1971. Veterinary Obstetrics and Genital Diseases $2^{\text {nd }}$ edn. Scientific Book Agency, Calcutta.

Sane C R, Kaikini A S, Deshpande B R, Koranne G S and Desai V G. 1964. Study of biometry of genitalia of the Murrah buffalo cows (Bos bubalis). Indian Vet J., 41: 653-63.

Savio J D, Keenan L, Boland M P and Roche J F.1988. Pattern of growth of dominant follicles during the oestrous cycle in heifers. J Reprod Fertil., 83: 663-71.

Singh S, Bansal M L, Singh T P and Kumar R. 1991. Statistical method for research workers. Kalyani Publishers, Ludhiana, India.

Stagg K, Diskin M G, Srenan J M and Roche J F. 1995. Follicular development in long-term anoestrous suckler beef cows fed two levels of energy postpartum. Anim Reprod Sci., 38: 49-61.

Zemjanis R. 1970 . Diagnostic and Therapeutic Techniques in animal reproduction. pp 15-20. Williams and Wilkins, Baltimore.

\section{How to cite this article:}

Manoj Gupta, V.K. Gandotra, A.S. Nanda and Honparkhe, M. 2018. Mensuration of Genitalia of Post-Partum Anestrous Murrah Buffaloes. Int.J.Curr.Microbiol.App.Sci. 7(10): 1504-1508. doi: https://doi.org/10.20546/ijcmas.2018.710.168 